Article

\title{
Optimizing Substrate Available Water and Coir Amendment Rate in Pine Bark Substrates
}

\author{
Nastaran Basiri Jahromi ${ }^{1, *}$, Amy Fulcher ${ }^{2} \mathbb{E}$, Forbes Walker ${ }^{1}$ and James Altland ${ }^{3}$ \\ 1 Department of Biosystems Engineering and Soil Science, University of Tennessee, 2506 E J Chapman Drive, \\ Knoxville, TN 37996, USA; frwalker@utk.edu \\ 2 Department of Plant Sciences, University of Tennessee, 2505 E J Chapman Drive, Knoxville, TN 37996, USA; \\ afulcher@utk.edu \\ 3 USDA Technology Application Unit, 1680 Madison Ave. Wooster, OH 44691, USA; \\ james.altland@ars.usda.gov \\ * Correspondence: nbasirij@vols.utk.edu
}

Received: 14 December 2019; Accepted: 24 January 2020; Published: 29 January 2020

\begin{abstract}
Water resources can be used more efficiently by including sustainable substrate components like coir that increase water-holding capacity. The first objective of this study was to evaluate the impact of coir amendment rate on plant available water and plant gas exchange, with the goal of optimizing substrate available water and determining the optimum coir amendment rate in a greenhouse environment. The second objective was to establish the optimum method of determining plant available water using either plant gas exchange parameters or substrate physical properties. Greenhouse experiments were conducted with Hydrangea paniculata 'Jane' (Little Lime ${ }^{\circledR}$ hardy hydrangea) potted with one of five different coir rates $(0 \%, 10 \%, 25 \%, 40 \%$ and $65 \%)$ mixed with pine bark on a volume basis. Plant gas exchange parameters and substrate water content were measured daily over a range of increasingly drier substrate moisture contents. Actual photosynthetic rates increased with increasing coir amendment rate and were highest with $65 \%$ coir amendment. Amending pine bark with coir increased the water storage capacity, plant available water, and plant gas exchange parameters. Results suggest that $65 \%$ coir amendment rate was the optimum amendment rate among those tested in a greenhouse environment and plant photosynthetic rate was the better method of determining plant available water.
\end{abstract}

Keywords: Hydrangea paniculate; moisture retention curve; nursery crops; on-demand irrigation; plant available water; water buffering capacity

\section{Introduction}

Agricultural irrigation is a major water consumer, responsible for about $70 \%$ of worldwide consumptive use [1] and about 30 percent of total withdrawals in the US [2]. Nursery production is an intensive form of agriculture that uses relatively large amounts of water, nutrients, and pesticides [3-5]. A typical container nursery in the USA consumes over $180 \mathrm{~m}^{3}$ water per hectare per day during the growing season [6]. Inefficient use of irrigation can exacerbate the present water shortages, and is likely to increase during drought, which results in imposing restrictions on irrigation [7]. Regulations currently limit water use in California, Delaware, Florida, Maryland, Michigan, North Carolina, Oregon, and Texas and are expected to become more stringent [8-10]. Developing management practices that make more efficient use of water is important for economically and environmentally viable production systems [11]. Water resources can be used more efficiently without the need for additional infrastructure by including more sustainable substrate components [12], including those that increase water-holding capacity or more efficiently deliver the water to the plant [13]. 
In the southeastern United States, pine bark is the most common substrate component in the nursery industry. Pine bark has high porosity and relatively low water holding capacity. Compared to field-grown plants, container-grown plants in pine bark require more frequent irrigation to provide adequate water for production [14]. Large particle sizes increase gravimetric pore space, which drain more easily compared to capillary and hygroscopic pore spaces that hold the water as thin films [15]. Substrate amendments can manipulate the average substrate particle size and reduce the proportion of larger-sized components, increasing the amount of available water, irrigation efficiency and plant growth [7]. In previous studies we used biochar as a substrate amendment and observed its positive effects on increasing water holding capacity, reduction of water and nutrient loss. Biochar amendment affects nutrient concentration and can act as a source of phosphorus and potassium depending on the feedstock type [16-19].

Coconut coir is another possible substrate amendment. Coconut fiber, known as coir, is a readily available, plant-derived by-product of the coconut (Cocos nucifera) industry [20]. Coir has a fibrous texture, which provides aeration and water holding capacity for plant roots [21]. In contrast to many horticultural substrate materials, such as peat or pine bark [21], coir has high rewetting capacity, which reduces the risk of hydrophobicity at low moisture levels [22,23], which may enhance conservative irrigation scheduling, irrigation efficiency and crop production [24]. Addition of coir to pine bark substrate can increase plant water availability by increasing substrate hydraulic conductivity, which may also produce marketable crops with less water while reducing time to market for container crops [13].

Photosynthetic rate has been successfully used as an irrigation-scheduling basis to improve crop water use efficiency [24-26]. Photosynthetic rate is related to stomatal conductance and both are impacted by as well as impact leaf water potential. Thus, photosynthesis can be used as a plant water status indicator [25]. The first objective of this study was to evaluate the impact of coir amendment rate on plant available water and plant gas exchange, with the goal of optimizing substrate available water and determining the optimum coir amendment rate in a greenhouse environment.

Some studies report plant available water potential can vary by substrate and can extend beyond the established threshold of $-10 \mathrm{kPa}$ tension for some substrates. Recent studies report a dynamic range of plant available water in different substrates or crop species $[13,27,28]$ and an extended range of plant available water potential $[13,29]$. The second objective was to evaluate two methods for determining plant available water (plant gas exchange parameters and substrate physical properties) and establish which of the two was better suited as a basis for irrigation scheduling.

\section{Materials and Methods}

Physical properties. Commercially available compressed $100 \%$ buffered coconut coir pith (Lynx Associates Inc., Oakland, NJ) was hydrated and stored in sealed plastic tubs for $24 \mathrm{~h}$ to facilitate moisture equilibrium prior to preparing the substrate blends. Pine bark was amended with $0 \%, 10 \%$, $25 \%, 40 \%$ or $65 \%$ coir by volume and packed in porometer cores to ensure uniformity and mimic substrate density in planted containers.

Substrate physical properties including air space, total porosity, container capacity, and bulk density were determined for the five substrates using the porometer procedure according to Fonteno and Harden [30], with three replications for each substrate (Table 1). Cores were attached to North Carolina State University Porometers ${ }^{\mathrm{TM}}$ (Horticultural Substrates Laboratory, North Carolina State University, Raleigh, NC) for physical properties measurements. Cores were saturated and then drained to determine air space (volume of drainage/core volume). Cores were weighed, oven dried for four days at $40{ }^{\circ} \mathrm{C}$, and weighed again to determine container capacity (wet weight-dry weight/core volume). Total porosity was calculated as the sum of air space and container capacity. Bulk density was determined using oven dried $\left(40^{\circ} \mathrm{C}\right)$ substrate in the same cores (dry weight/core volume). Data were analyzed using mixed models analysis of variance (SAS v9.4, Cary, NC). 
Table 1. Physical properties ${ }^{\mathrm{z}}$ of pine bark substrates amended with $0 \%, 10 \%, 25 \%, 40 \%$ or $65 \%$ of coir by volume $(n=3)$.

\begin{tabular}{ccccc}
\hline Coir Rate (\%) & Total Porosity (\%) & Air Space (\%) & Container Capacity (\%) & Bulk Density $\mathbf{( g / \mathbf { c m } ^ { 3 } )}$ \\
\hline 0 & $69 \pm 3$ & $30 \pm 0 \mathrm{a}^{\mathrm{y}}$ & $39 \pm 0.03 \mathrm{c}$ & $0.18 \pm 0 \mathrm{a}$ \\
10 & $79 \pm 2$ & $35 \pm 0.01 \mathrm{a}$ & $44 \pm 0.01 \mathrm{bc}$ & $0.18 \pm 0 \mathrm{a}$ \\
25 & $77 \pm 3$ & $29 \pm 0.04 \mathrm{a}$ & $48 \pm 0.02 \mathrm{~b}$ & $0.16 \pm 0 \mathrm{~b}$ \\
40 & $77 \pm 3$ & $29 \pm 0.02 \mathrm{a}$ & $48 \pm 0.02 \mathrm{~b}$ & $0.14 \pm 0.01 \mathrm{c}$ \\
65 & $81 \pm 3$ & $21 \pm 0.03 \mathrm{~b}$ & $59 \pm 0.02 \mathrm{a}$ & $0.11 \pm 0 \mathrm{~d}$ \\
$P$-value & 0.0600 & 0.0300 & 0.0006 & $<0.0001$ \\
\hline
\end{tabular}

${ }^{\mathrm{y}}$ Values in same column with same letter are not significantly different at $P<0.0500 .{ }^{\mathrm{z}}$ Substrate physical properties were determined using a $15-\mathrm{cm}$ tall porometer.

Moisture characteristic curves were developed for the five-substrate blends using the Hyprop instrument (UMS, Munich, Germany) with the evaporative method [13]. Substrates were packed to the same bulk density as for porometer procedure, saturated from the bottom, drained, and then placed on a scale connected to a computer. Water potential from the two tensiometers and total weight were recorded as volumetric water content (VWC) decreased via evaporation. The relationship between moisture tension and VWC was developed using HypropFit software (UMS, Munich, Germany) (Figure 1).

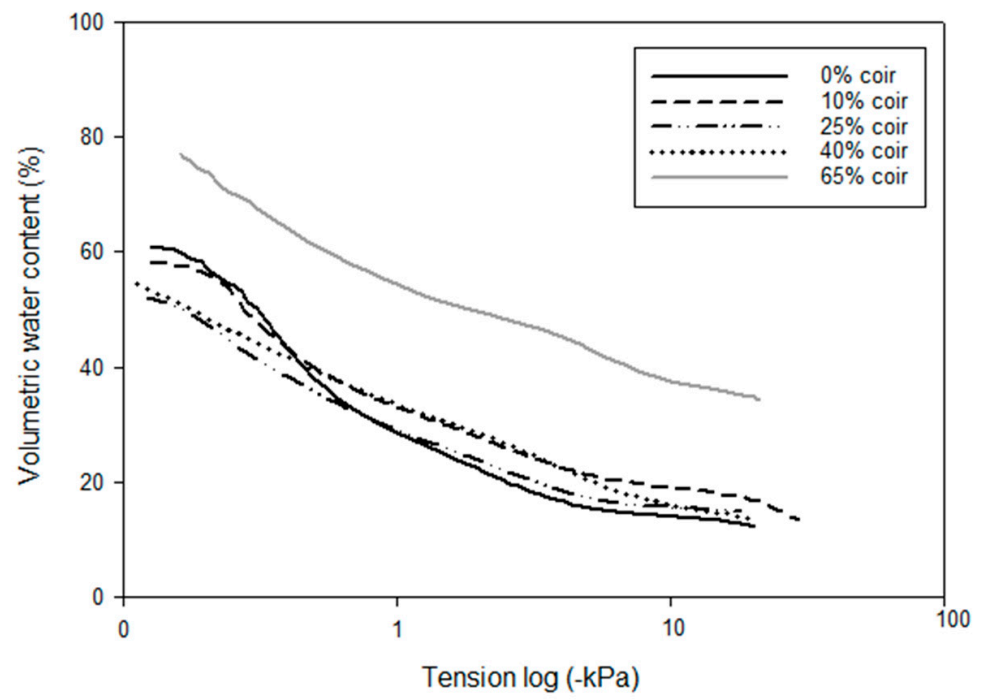

Figure 1. Moisture characteristic curves for pine bark substrates with $0 \%, 10 \%, 25 \%, 40 \%$ or $65 \%$ of coir by volume with the evaporative method using the Hyprop.

Sensor Calibration. Prior to initiating the greenhouse experiments, moisture sensors were calibrated individually for each of the five-pine bark and coir substrates due to variations in substrate texture and bulk density for best possible accuracy of VWC measurements. Pine bark was mixed with pre-hydrated coir at $0 \%, 10 \%, 25 \%, 40 \%$ and $65 \%$ by volume and then air dried in the greenhouse to decrease the VWC.

Batches of air-dried substrate were mixed with water to create the three predetermined VWC levels. The mass of dried substrate was calculated using the bulk density from porometer data and pot volume (bulk density $\times$ pot volume $=$ mass of dry substrate) and mass of water was calculated using the VWC and pot volume $\left(\right.$ VWC $\times$ pot volume $=$ volume of water $\left.=\mathrm{g} \mathrm{H}_{2} \mathrm{O}\right)$. Mixes were stored in sealed buckets overnight to facilitate moisture equilibrium. After equilibrium, substrates were used to fill the same production containers as for the experiment but with sealed drainage holes, and the substrate surface was covered with plastic to reduce evaporation. Sensors were tested individually in the same orientation in the container as the experiment. The millivolt measured by each sensor in each predetermined VWC was recorded. For all sensors, the equations had $r^{2}$ greater than 0.90 . 
The initial air-dried substrate contains a small amount of moisture, which added moisture to the predetermined VWC. In order to calculate the actual substrate water content, each substrate's wet weight was recorded and then substrates were oven dried at $40^{\circ} \mathrm{C}$ until there was no change in weight. The actual VWC was calculated and used for model development (Figure 1). The relationship between VWC and raw sensor millivolt output was graphed. Linear regression was fit to the data and the line equation was used as the calibration equation for each sensor in the datalogger program.

Greenhouse experiment. The greenhouse experiments were conducted at the University of Tennessee North Greenhouse Complex, Knoxville, Tennessee ( $\left.35.9606^{\circ} \mathrm{N}, 83.9207^{\circ} \mathrm{W}\right)$. Supplemental lighting was used in the greenhouse when outside light conditions were below $400 \mu \mathrm{mol} \mathrm{CO} \mathrm{Cm}^{-2} \cdot \mathrm{s}^{-1}$, and the photoperiod was set to $16 \mathrm{~h}$ (light from $7 \mathrm{a}$.m. to 11 p.m.). The daytime and nighttime thermostat set points were 26 and $18{ }^{\circ} \mathrm{C}$, respectively. Little Lime ${ }^{\circledR}$ hardy hydrangea (Hydrangea paniculata 'Jane') liners (5.7 cm, Spring Meadow Nursery Inc., Grand Rapids, MI, USA) were potted into 7.6 L containers with the substrate intact on 13 July 2018 and 6 October 2018. Container substrates consisted of pine bark amended with $0 \%, 10 \%, 25 \%, 40 \%$ or $65 \%$ coir by volume. Coir rates were selected to test a wide percentage range of substrate amendment. Including $10 \%$ and $25 \%$ coir enabled comparison with results from previous research with biochar [16]. Positive results from other research with $35 \%$ coir as a substrate amendment $[13,31]$ supported including higher rates to begin to define the highest rate at which benefits would be derived and provide producers with recommendations. The experiment was a complete randomized block design with eight replications and was conducted twice, once in summer and then repeated in the fall.

Plants were fertilized with $40 \mathrm{~g}$ per container of $18 \mathrm{~N}-2.6 \mathrm{P}-9.9 \mathrm{~K}$ controlled release fertilizer (Osmocote, Everris, Marysville, OH, USA). Before the dry down began plants were irrigated once every day until the roots reached the container sidewall and then hand watered and soaked in water for an hour to evenly saturate the substrate, and drained to container capacity. The experiment was initiated on 13 August 2018 and 6 November 2018 after 4 weeks of growth by withholding irrigation for the experiment duration. Plant gas exchange parameters were measured over a range of increasingly dry substrate moisture contents using an infrared gas analyzer (LI-6400, LI-COR, Lincoln, NE, USA) following Fulcher et al. [25]. Measurements were taken daily at $390 \mathrm{mg} \cdot \mathrm{L}^{-1}$ carbon dioxide $\left(\mathrm{CO}_{2}\right)$ and $1500 \mu \mathrm{mol} \cdot \mathrm{m}^{-2} \cdot \mathrm{s}^{-1}$ light intensity on the most fully expanded, recently matured leaf of eight replications from each treatment. Substrate weight and water content were recorded at the same time as gas exchange measurements. Substrate VWC was estimated using capacitance sensors (ECHO-5, Decagon Devices Inc., Pullman, WA, USA) connected to a data logger (CR1000, Campbell Scientific Inc., Logan, UT, USA). Instantaneous water use efficiency (Net photosynthetic rate/Transpiration rate) and intrinsic water use efficiency (Net photosynthetic rate/Stomatal conductance) were calculated. Graphing and data analysis software (SigmaPlot v 14, San Jose, CA, USA) was used to determine a predictive curve that best fit the data. The gas exchange data followed the same patterns in both seasons so just the summer (August 2018) experiment data is included in this manuscript.

\section{Results and Discussion}

\subsection{Physical Properties}

There was no change in total porosity, while air space decreased and container capacity increased with incorporation of $65 \%$ coir compared to the other rates (Table 1). Increasing coir rate from 0 to $25 \%$ increased container capacity but decreased substrate bulk density compared to $0 \%$ and $10 \%$ treatments. Substrate amended with $65 \%$ coir has the highest container capacity and lowest air space of all substrates, which makes it the ideal composition of the rates tested in this greenhouse study. 
Coir has a fibrous texture with fine particles that fill large pore spaces between coarse pine bark particles. Adding coir increases pore connectivity and decreases the proportion of large pores, which consequently decreases air space and increases water-holding capacity compared to $0 \%$ coir. Substrate air space and total porosity were within the recommended range of $10 \%$ to $30 \%$ for air space and $50 \%$ to $85 \%$ for total porosity [32]. However, the bulk density of $25 \%$ and higher rates of coir-amended substrates were lower than the recommended range of 0.19 to $0.70 \mathrm{~g} \cdot \mathrm{cm}^{-3}$ by Bilderback et al. [32]. Container capacity for the $0 \%$ coir substrate was lower than the recommended range of $45 \%$ to $65 \%$; however, coir amendment greater than $10 \%$ resulted in container capacity within the recommended range.

Moisture characteristic curves for each substrate were developed with the evaporative method (Figure 1). Substrates with 65\% coir amendment had the highest moisture content compared to other treatments at all tension levels. Additionally plant available water, which is usually defined as VWC between $-1 \mathrm{kPa}$ and $-10 \mathrm{kPa}$ water tension [33] and includes easily available water ( -1 to $-5 \mathrm{kPa})$ and water buffering capacity ( -5 to $-10 \mathrm{kPa}$ ) [34] was higher in substrates amended with $25 \%, 40 \%$ and $65 \%$ coir. Plant available water was $14 \%, 14.1 \%, 15 \%, 16.9 \%$, and $16.4 \%$ in $0 \%, 10 \%, 25 \%, 40 \%$ and $65 \%$ coir treatments, respectively. Coir amendment improved water usage through better water retention and water availability while still possessing the other desirable characteristics of a potting medium such as pore space for oxygen availability.

The fibrous texture of coir amendment increased the amount of water retained by the substrate in $65 \%$ treatment and also the plant available water in $25 \%$ and higher coir rates. Caron et al. [7] reported that changing substrate particle size distribution with various particle size components increases plant available water that would improve irrigation efficiency and plant growth. Specifically, manipulating substrate components with coir amendment increases substrate pore uniformity and connectivity, which increases substrate hydraulic conductivity and plant water use [35].

\subsection{Plant Gas Exchange Parameters}

The relationship between plant gas exchange parameters (photosynthetic rate, transpiration rate and stomatal conductance) and substrate moisture content were compared for the different coir treatments (Figure 2). Data were fit with several types of curves (linear, polynomial and sigmoidal) and the best fitting curve was chosen based on the $r^{2}$ and the trends that matches the pattern of data. The 3-parameter sigmoidal curve was chosen as the best fitting curve describing the relationship between plant gas exchange and substrate moisture content due to its high $r^{2}$ and given that the S-shaped curve follows the pattern of data (Table 2). The S-shaped curve is frequently used for growth and helps describe response when there is a limiting factor, substrate moisture content in this study. Other studies reported the same modeling of plant gas exchange parameters and substrate moisture content in different substrates and plant species [24-26]. This model can be used as an irrigation-scheduling basis by allowing users to select a set point to actuate irrigation that will minimize water use and maximize plant photosynthesis (Table 2). 

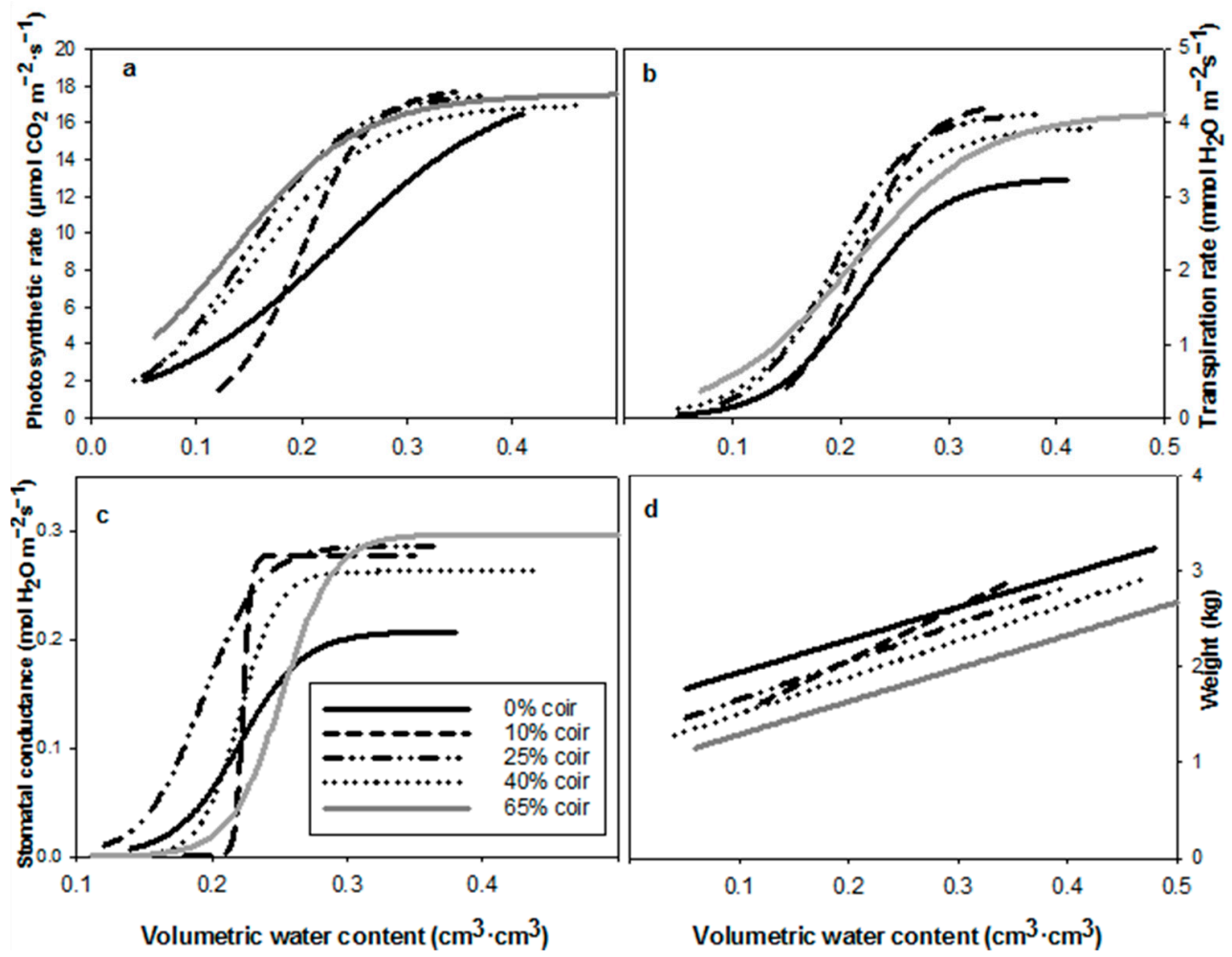

Figure 2. The relationship between plant photosynthetic rate (a), transpiration rate (b), stomatal conductance (c) and container weight (d) with substrate volumetric water content (VWC) of Hydrangea paniculata 'Jane' (Little Lime ${ }^{\circledR}$ hardy hydrangea) plants grown in a pine bark substrate amended with $0 \%, 10 \%, 25 \%, 40 \%$ or $65 \%$ of coir by volume in August 2018. Data for photosynthetic rate, transpiration rate, stomatal conductance were characterized by a 3 parameter sigmoidal curve while container weight was characterized by a simple linear relationship. Each line represents one treatment from eight replications $(\mathrm{n}=8)$. a = photosynthetic rate and $\mathrm{VWC}, \mathrm{b}=$ transpiration rate and $\mathrm{VWC}, \mathrm{c}=$ stomatal conductance and VWC, $\mathrm{d}=$ weight and VWC.

The relationship between substrate moisture content and weight was characterized by a linear curve and has the highest $r^{2}$ (0.75 to 0.90$)$ compared to the relationship between plant gas exchange parameters and substrate water content (Table 2). The gravimetric data can be used as a reference for evaluating the moisture sensors' performance in predicting substrate VWC in order to obtain the highest possible accuracy. Coir substrates, particularly the $65 \%$ coir treatment, weighed less (Figure 2) but had more available water compared to the other treatments (Figure 1), which could add to the benefits of using coir amendment to reduce water use, shipping costs and worker strain. However, a lighter substrate may be more prone to tipping over when a top-heavy crop is grown. 
Table 2. Fit model parameters for the relationship between plant gas exchange, weight, and substrate volumetric water content (VWC) for Hydrangea paniculata 'Jane' (Little Lime ${ }^{\circledR}$ hardy hydrangea) grown in a pine bark substrate amended with $0 \%, 10 \%, 25 \%, 40 \%$ or $65 \%$ of coir by volume. The models' $r^{2}$ are provided in the last column of the table.

\begin{tabular}{|c|c|c|c|c|}
\hline \multicolumn{5}{|c|}{ Photosynthetic Rate $=a /\left(1+\exp \left(-\left(V W C-x_{0}\right) / b\right)\right)$} \\
\hline Treatment & a & $\mathbf{x}_{0}$ & b & $r^{2}$ \\
\hline $0 \%$ coir & 18.59 & 0.23 & 0.09 & 0.57 \\
\hline $10 \%$ coir & 17.85 & 0.23 & 0.03 & 0.68 \\
\hline $25 \%$ coir & 17.64 & 0.15 & 0.05 & 0.60 \\
\hline $40 \%$ coir & 17.00 & 0.16 & 0.06 & 0.60 \\
\hline $65 \%$ coir & 17.56 & 0.13 & 0.06 & 0.64 \\
\hline \multicolumn{5}{|c|}{ Transpiration Rate $=a /\left(1+\exp \left(-\left(V W C-x_{0}\right) / b\right)\right)$} \\
\hline Treatment & $\mathrm{a}$ & $\mathrm{x} 0$ & $\mathrm{~b}$ & $r^{2}$ \\
\hline $0 \%$ coir & 3.25 & 0.21 & 0.04 & 0.47 \\
\hline $10 \%$ coir & 4.27 & 0.22 & 0.03 & 0.68 \\
\hline $25 \%$ coir & 4.12 & 0.19 & 0.04 & 0.65 \\
\hline $40 \%$ coir & 3.94 & 0.20 & 0.04 & 0.46 \\
\hline $65 \%$ coir & 4.14 & 0.21 & 0.06 & 0.63 \\
\hline \multicolumn{5}{|c|}{ Stomatal Conductance $=a /\left(1+\exp \left(-\left(V W C-x_{0}\right) / b\right)\right)$} \\
\hline Treatment & $\mathrm{a}$ & $\mathrm{x}_{0}$ & $\mathrm{~b}$ & $r^{2}$ \\
\hline $0 \%$ coir & 0.21 & 0.22 & 0.02 & 0.51 \\
\hline $10 \%$ coir & 0.28 & 0.22 & 0.00 & 0.42 \\
\hline $25 \%$ coir & 0.29 & 0.19 & 0.02 & 0.54 \\
\hline $40 \%$ coir & 0.26 & 0.22 & 0.01 & 0.45 \\
\hline $65 \%$ coir & 0.30 & 0.50 & 0.02 & 0.55 \\
\hline \multicolumn{5}{|c|}{ Weight $=y_{0}+a \times V W C$} \\
\hline Treatment & & & $\mathrm{a}$ & $r^{2}$ \\
\hline $0 \%$ coir & & & 3.40 & 0.75 \\
\hline $10 \%$ coir & & & 5.55 & 0.76 \\
\hline $25 \%$ coir & & & 3.94 & 0.90 \\
\hline $40 \%$ coir & & & 3.81 & 0.89 \\
\hline $65 \%$ coir & & & 3.45 & 0.87 \\
\hline
\end{tabular}

The sigmoidal relationship between VWC and plant gas exchange, specifically the maximum or near maximum gas exchange rate over a range of moisture levels, was consistent with that of 'Silver Dollar' hydrangea and hibiscus 'Cashmere Wind' grown in substrates containing pine bark, peat moss, and/or biochar $[25,27,36]$. Coir treatments supported a higher maximum predicted photosynthetic rate in comparison to the non-amended pine bark. Maximum predicted transpiration rate and stomatal conductance were also greater in coir treatments compared to the non-amended pine bark substrate and peaked higher when coir was included. Coir amendments to pine bark increased crops gas exchange parameters, which might be due to higher plant available water in coir-amended substrates.

The relationship between photosynthetic rate and substrate water content was stronger than stomatal conductance and transpiration rate and appears to be the most appropriate gas exchange-based indicator of water stress for Little Lime ${ }^{\circledR}$ hydrangea. The relationship between both instantaneous water use efficiency and intrinsic water use efficiency and VWC was poor in this study $\left(r^{2} \leq 0.46\right)$. Photosynthetic rate is closely associated with stomatal conductance and plant hydration level. Photosynthetic rate and stomatal conductance both impact and are impacted by leaf water potential; therefore, photosynthesis can be used as an index of plant water status [25].

Photosynthetic rate can be used as irrigation scheduling basis to actuate irrigation at the VWC that was calculated to maintain the predicted maximum photosynthetic rate. Maintaining VWC that corresponds to a predicted maximum photosynthetic rate may result in water savings without restricting 
crop growth. The maximum predicted photosynthetic rate was $11,15.3,16,15.3,16.9 \mu \mathrm{mol} \cdot \mathrm{m}^{-2} \cdot \mathrm{s}^{-1}$ and occurs at $0.27,0.26,0.25,0.28$ and $0.33 \mathrm{~cm}^{3} \cdot \mathrm{cm}^{-3}$ for $0 \%, 10 \%, 25 \%, 40 \%$ or $65 \%$ of coir by volume respectively. The $65 \%$ coir treatment has a higher VWC as an irrigation set point and would reach the set point more frequently but needs less volume of water in each irrigation event, which might reduce the irrigation volume.

The relationship between photosynthetic rate and substrate water content was similar regardless of the season and showed that coir amended substrates supported the higher maximum predicted photosynthetic rates compared to the $0 \%$ coir treatment. At the termination of the experiment, plants in coir-amended substrate had a higher photosynthetic rate, nearly double photosynthetic rate in $65 \%$ coir treatment compared to $0 \%$ coir treatment. The higher maximum predicted photosynthetic rate might be due to higher plant available water in substrates amended with coir, as water is one of the most important factors affecting photosynthetic rate and growth. Based on the moisture retention curves, coir treatments have greater plant available water compared to the pine bark treatment (Figure 1).

Plant gas exchange parameters were affected by substrate type and more specifically by substrate water availability. The actual photosynthetic rates increased with increasing coir amendment rate; the highest actual photosynthetic rate was in plants grown in $65 \%$ coir amendment $\left(19.2 \mu \mathrm{mol} \cdot \mathrm{m}^{-2} \cdot \mathrm{s}^{-1}\right)$. Based on the moisture retention curve data, the $65 \%$ coir treatment had the highest water content and highest available water, which corresponded to the highest photosynthetic rate. The maximum actual photosynthetic rate was observed at a higher VWC in $65 \%$ coir treatment $\left(0.33 \mathrm{~cm}^{3} \cdot \mathrm{cm}^{-3}\right)$ compared to other coir treatments. The VWC corresponding to the maximum photosynthetic rate was comparable for $0 \%, 10 \%, 25 \%$, and $40 \%$ coir treatments $\left(\sim 0.26 \mathrm{~cm}^{3} \cdot \mathrm{cm}^{-3}\right)$ consistent with moisture retention curve data. However, 10\%, 25\% and 40\% coir treatments have higher actual photosynthetic rates (15.6, 16, $14.6 \mu \mathrm{mol} \cdot \mathrm{m}^{-2} \cdot \mathrm{s}^{-1}$ ) compared to the $0 \%$ coir treatment. Coir-amended substrates have higher plant available water at high and low VWCs (Figure 1), which would benefit the plants at both higher and lower tensions and support higher gas exchange rates. A greater portion of water is available for plants in coir-amended substrates, which might reduce crop irrigation requirements. Addition of coir to pine bark substrate increased plant water availability, possibly by increasing substrate hydraulic conductivity (changing substrate physical properties), as demonstrated by a higher photosynthetic rate in coir treatments compared to the $0 \%$ coir treatment.

Plants grown in 25\%, 40\% and 65\% coir substrates had a higher predicted photosynthetic rate at VWC (Figure 2) corresponding to a lower tension than the defined water buffering capacity. At the end of the experiment photosynthesis occurred at a lower VWC than the greatest tension associated with plant available water. The maximum photosynthetic rate in $65 \%$ coir substrate occurred at lower VWC $\left(0.33 \mathrm{~cm}^{3} \cdot \mathrm{cm}^{-3}\right)$ than water buffering capacity $\left(0.44 \mathrm{~cm}^{3} \cdot \mathrm{cm}^{-3}\right)$, which increased the available water to $21 \%$ from $16.42 \%$. In the $65 \%$ coir treatment, $60 \%$ of total water holding capacity can be extracted without decreases in photosynthetic rate.

This study showed that plant available water potential can be different in different substrates and it can extend beyond $-10 \mathrm{kPa}$ tension for some substrates. Other recent studies also reported a dynamic range of plant available water depending on substrate type, or plant species $[13,27,28]$ and an extended range of plant available water potential $[13,29]$. Our results showed that species-specific plant available water and water buffering capacity determination in the greenhouse using plant gas exchange parameters are a more accurate approach than the laboratory-based tests that consider $-10 \mathrm{kPa}$ tension as the end range of water buffering capacity. Plant physiological parameters can effectively estimate crop water requirements.

This research was initiated to better understand plant available water in soilless substrates and may inform future irrigation technology adoption by the green industry. An increasing amount of literature suggests that irrigation set points can be determined through plant-based model development experiments and adopted as conservative irrigation systems for nursery production with minimal species-specific development [25,26] and some other woody crops [37]. Moreover, in previous studies plant physiology based irrigation models were developed in the greenhouse and then evaluated for a 
production cycle outdoors, which resulted in water savings compared to the traditional practice of irrigating 1.8 to $2.54 \mathrm{~cm}$ of water per day [24,27]. Model development could be conducted by consultants using those species that are grown in the greatest numbers and thus affect a disproportionate amount of water use. Crops with similar set points would populate the same irrigation zone and irrigated using the developed set points, or set points could be converted to weight-based thresholds to limit the need for specialized instrumentation and technical expertise.

To adopt a system such as described in this research, producers would incur initial and on-going costs. One of the costs of a sensor-based system would be the sensors themselves and the added labor expense due to additional time spent installing them and uninstalling them prior to harvest [24]. Sensors may be damaged or misplaced and become a reoccurring expense. Belayneh et al. [38] showed that even with a modest cost for water (\$326 per acre-foot) the payback period of a sensor-based irrigation system for a container crop was less than 4 months. The payback period is anticipated to be much shorter in locations such as Southern California in which the current cost can be $\$ 1341$ per acre-foot [39]. Moreover, any reduction in water use will help arid regions address the water-energy nexus [40]. Plant-based irrigation systems have the potential to lessen costs and ultimately improve profitability beyond the direct savings from a reduction in water expense. For example, a reduction in production time, which contributed to a 1.5 fold increase in profit, has been associated with sensor-based irrigation systems [41]. Likewise, Lichtenburg et al. [41] calculated annualized profit increased approximately $\$ 2.80 \mathrm{ft}^{2}$, in part due to a reduction in crop mortality from root rot as well as reduced need for fungicide application [42]. Plant-based irrigation scheduling improves water and nutrient use efficiency and proactively addresses nutrient and agrichemicals in container effluent by reducing runoff [43]. Therefore, precision irrigation could reduce not just the cost of water, but also costs associated with labor, energy, fertilizer, crop mortality, production period [44] as well as environmental costs.

\section{Conclusions}

This research demonstrated that improvement in pine bark substrate physical properties, water storage capacity, distribution and delivery to the plant can be achieved by using sustainable substrate amendments such as coconut coir. Addition of coir to pine bark substrate appears to increase plant water availability, which increased plant gas exchange rates. Of the rates tested in this greenhouse experiment, the highest rate, $65 \%$ coir, was the ideal rate of coir amendment to pine bark. Actual photosynthetic rates increased with increasing coir amendment rate and were highest in $65 \%$ coir amendment rates. Compared to other gas exchange parameters, photosynthetic rate was a better indicator of plant water status due to its high $r^{2}$ and can be used for irrigation scheduling. Plant available water potential varies with substrates and can extend beyond $-10 \mathrm{kPa}$ tension for some substrates (65\% coir). In this greenhouse study with Little Lime ${ }^{\circledR}$ hydrangea, plant photosynthetic rate accurately estimated plant available water by integrating plant available water in the substrate and accounting for species-specific effects on plant available water. Future research should include examining these and higher coir amendment rates with a range of plant species, and should include experiments conducted outdoors for a typical production period in order to assess the effects of environmental conditions, including rainfall, on the results and begin to understand its feasibility and limitations for ornamental crop producers using controlled environments as well as outdoor production. Additionally, cost feasibility studies should be conducted to determine if consulting and instrumentation expenses necessary to implement a gas exchange-based irrigation schedule would outweigh the financial savings from reduced water and pumping costs.

Author Contributions: Conceptualization, N.B.J., and A.F.; methodology, N.B.J., A.F., and J.A.; formal analysis, N.B.J.; investigation, N.B.J.; resources, A.F., J.A., and F.W.; data curation, N.B.J.; writing-original draft, N.B.J.; writing-review \& editing, N.B.J. A.F, J.A, and F.W.; supervision, A.F., and F.W.; funding acquisition, F.W. All authors have read and agreed to the published version of the manuscript. 
Funding: This project was supported by Agriculture and Food Research Initiative Competitive Award No. \#2015-68007-23212 from the USDA National Institute of Food and Agriculture and Hatch TEN00512 and NC118.

Acknowledgments: The authors wish to acknowledge the USDA National Institute of Food and Agriculture for financial support, and Lynx Associates Inc., Oakland, New Jersey for coconut coir and Osmocote ${ }^{\circledR}$ for fertilizer. The authors gratefully acknowledge Neal Eash, Wesley Wright, Lauren Fessler, Grace Pietsch, Sterling Mcclanahan and Lori Osburn for their contributions and Arnold Saxton for statistical analysis.

Conflicts of Interest: The authors declare no conflict of interest.

\section{References}

1. Food and Agricultural Organization of the United Nations, Coping with Water Scarcity. 2007. Available online: http://www.fao.org/nr/water/docs/escarcity.pdf (accessed on 26 February 2013).

2. Kenny, J.F.; Barber, N.L.; Hutson, S.S.; Linsey, K.S.; Lovelace, J.K.; Maupin, M.A. Estimated use of water in the United States in 2005. U.S. Geological Survey, Reston, VA. Circular 2009, 1344, 52.

3. Beeson, R.C. Modeling actual evapotranspiration of Viburnum odoratissimum during production from rooted cuttings to market size plants in 11.4-L containers. Hortic. Sci. 2010, 45, 1260-1264. [CrossRef]

4. Bethke, J.A.; Cloyd, R.A. Pesticide use in ornamental production: What are the benefits? Pest Manag. Sci. 2009, 65, 345-350. [CrossRef] [PubMed]

5. Wilson, P.C.; Albano, J.P. Impact of fertigation versus controlled-release fertilizer formulations on nitrate concentrations in nursery drainage water. Hortic. Technol. 2011, 21, 176-180. [CrossRef]

6. Fulcher, A.; Fernandez, T. Sustainable nursery irrigation management series: Part, I. Water use in nursery production. Univ. Tenn. Bul. 2013, W287.

7. Caron, J.; Elrick, D.E.; Beeson, R.; Boudreau, J. Defining critical capillary rise properties for growing media in nurseries. Soil Sci. Soc. Am. J. 2005, 69, 794-806. [CrossRef]

8. Beeson, R.C., Jr.; Arnold, M.A.; Bilderback, T.E.; Bolusky, B.; Chandler, S.; Gramling, H.M.; Lea-Cox, J.D.; Harris, J.R.; Klinger, P.J.; Mathers, H.M.; et al. Strategic vision of container nursery irrigation in the next ten years. J. Environ. Hortic. 2004, 22, 113-115.

9. Majsztrik, J.C.; Fernandez, R.T.; Fisher, P.R.; Hitchcock, D.R.; Lea-Cox, J.; Owen, J.S.; Oki, L.R.; White, S.A. Water use and treatment in container-grown specialty crop production: A review. Water Air Soil Pollut. 2017, 228, 151. [CrossRef]

10. State of Michigan. Public Act 148, 2003. Available online: http://www.legislature.mi.gov/documents/20032004/publicact/htm/2003-PA-0148.htm (accessed on 22 January 2020).

11. Fulcher, A.; LeBude, A.V.; Owen, J.S.; White, S.A.; Beeson, R.C. The next ten years: Strategic vision of water resources for nursery producers. Hortic. Technol. 2016, 26, 121-132. [CrossRef]

12. Barrett, G.E.; Alexander, P.D.; Robinson, J.S.; Bragg, N.C. Achieving environmentally sustainable growing media for soilless plant cultivation systems-A review. Sci. Hortic. 2016, 212, 220-234. [CrossRef]

13. Fields, J.S.; Owen, J.S.; Scoggins, H.L. The influence of substrate hydraulic conductivity on plant water status of an ornamental container crop grown in suboptimal substrate water potentials. Hortic. Sci. 2017, 52, 1419-1428. [CrossRef]

14. Hoskins, T.C.; Owen, J.S.; Niemiera, A.X. Water movement through a pine-bark substrate during irrigation. Hortic. Sci. 2014, 49, 1432-1436. [CrossRef]

15. Altland, J.E.; Owen, J.S.; Jackson, B.E.; Fields, J.S. Physical and hydraulic properties of commercial pine-bark substrate products used in production of containerized crops. Hortic. Sci. 2018, 53, 1883-1890. [CrossRef]

16. Basiri Jahromi, N.; Walker, F.; Fulcher, A.; Altland, J.; Wright, W.C. Growth response, mineral nutrition, and water utilization of container-grown woody ornamentals grown in biochar-amended pine bark. Hortic. Sci. 2018, 53, 347-353.

17. Basiri Jahromi, N. Improving Water Use Efficiency of Containerized Crops Using Biochar and Precision Irrigation Scheduling. Ph.D. Thesis, University of Tennessee, Knoxville, TN, USA, 2019.

18. Basiri Jahromi, N.; Walker, F.; Fulcher, A.; Altland, J. Photosynthesis, growth, and water use of Hydrangea paniculata 'Silver Dollar' produced with different irrigation schedules and biochar substrate amendment. Hortic. Sci. 2017, 52, S273-S274.

19. Basiri Jahromi, N.; Walker, F.; Fulcher, A. What is biochar and how different biochars can improve your crops. UT Ext. 2019, W829. 
20. Arenas, M.; Vavrina, C.S.; Cornell, J.A.; Hanlon, E.A.; Hochmuth, G.J. Coir as an alternative to peat in media for tomato transplant production. Hortic. Sci. 2002, 37, 309-312. [CrossRef]

21. Michel, J.C. The physical properties of peat: A key factor for modern growing media. Mires Peat 2010, 6, 1-6.

22. Blok, C.; Wever, G. Experience with selected physical methods to characterize the suitability of growing media for plant growth. Acta Hortic. 2008, 779, 239-249. [CrossRef]

23. Hagen, E.; Fulcher, A.; Sun, X. Determining sensor orientation and depth within an $11.4 \mathrm{~L}$ container to estimate whole container volumetric water content. Appl. Eng. Agric. 2015, 31, 597-603.

24. Hagen, E.; Nambuthiri, S.; Fulcher, A.; Geneve, R. Comparing substrate moisture-based daily water use and on-demand irrigation regimes for oakleaf hydrangea grown in two container sizes. Hortic. Sci. 2014, 179, 132-139. [CrossRef]

25. Fulcher, A.; Buxton, J.W.; Geneve, R.L. Developing a physiological-based, on-demand irrigation system for container production. Hortic. Sci. 2012, 138, 221-226. [CrossRef]

26. Nambuthiri, S.; Hagen, E.; Fulcher, A.; Geneve, R. Evaluating a physiological-based, on-demand irrigation system for container-grown woody plants with different water requirements. Hortic. Sci. 2017, 52, 251-257. [CrossRef]

27. Basiri Jahromi, N.; Fulcher, A.; Walker, F.; Altland, J.; Wright, W.; Eash, N. Evaluating on-demand irrigation systems for container-grown woody plants grown in biochar-amended pine bark. Hortic. Sci. 2018, 53, 1891-1896.

28. O'Meara, L.; Chappell, M.R.; van Iersel, M.W. Water use of Hydrangea macrophylla and Gardenia jasminoides in response to a gradually drying substrate. Hortic. Sci. 2014, 49, 493-498. [CrossRef]

29. Montesano, F.F.; van Iersel, M.W.; Boari, F.; Cantore, V.; D’Amato, G.; Parente, A. Sensor-based irrigation management of soilless basil using a new smart irrigation system: Effects of set-point on plant physiological responses and crop performance. Agric. Water Manag. 2018, 203, 20-29. [CrossRef]

30. Fonteno, W.C.; Harden, C.T. North Carolina state university horticultural substrates lab manual. N. C. State Univ. Raleigh NC 2010, 49, 827-832.

31. Fulcher, A.; Fessler, L.; Piestch, G.; Wright, W. Improving plant available water during container production through leaching fraction-based irrigation scheduling and coir substrate amendment. Unpublished work, 2020.

32. Bilderback, T.; Boyer, C.; Chappell, M.; Fain, G.; Fare, D.; Gilliam, C.; Jackson, B.E.; Lea-Cox, J.; LeBude, A.V.; Niemiera, A.; et al. Best Management Practices: Guide for Producing Nursery Crops, 3rd ed.; Southern Nursery Association: Acworth, GA, USA, 2013.

33. Arguedas-Rodriguez, F.R. Calibrating Capacitance Sensors to Estimate Water Content, Matric Potential, and Electrical Conductivity in Soilless Substrates. Master's Thesis, University of Maryland, Baltimore, MD, USA, 2009; p. 118.

34. de Boodt, M.; Verdonck, O. The physical properties of substrates in horticulture. Acta Hortic. 1972, 26, 37-44. [CrossRef]

35. Fields, J.S.; Owen, J.S.; Altland, J.E.; van Iersel, M.W.; Jackson, B.E. Soilless substrate hydrology can be engineered to influence plant water status for an ornamental containerized crop grown within optimal water potentials. J. Amer. Soc. Hortic. Sci. 2018, 143, 268-281. [CrossRef]

36. Fulcher, A.; Geneve, R.L. Relationship between photosynthesis and substrate moisture for container-grown Hibiscus and Cornus. Acta Hortic. 2011, 922, 183-186. [CrossRef]

37. Fernández, J.E. Plant-based methods for irrigation scheduling of woody crops. Horticulturae 2017, 3, 35. [CrossRef]

38. Belayneh, B.E.; Lea-Cox, J.D.; Lichtenberg, E. Costs and benefits of implementing sensor-controlled irrigation in a commercial pot-in-pot container nursery. Hortic. Technol. 2013, 23, 760-769. [CrossRef]

39. San Diego County Water Authority. Water Authority's Proposed 2019 Rate Increases Smallest in Years. Available online: https://www.sdcwa.org/water-authoritys-proposed-2019-rate-increases-smallest-years. (accessed on 20 January 2018).

40. Advanced Energy Economy. Bringing California's Water-Energy System Into the 21st Century Addressing Greenhouse Gas Emissions Through Technology. Available online: https://info.aee.net/bringing-californiaswater-energy-system-into-the-21st-century (accessed on 20 January 2020).

41. Lichtenberg, E.; Majsztrik, J.; Saavoss, M. Profitability of sensor-based irrigation in greenhouse and nursery crops. Hortic. Technol. 2013, 23, 770-774. [CrossRef] 
42. Chappell, M.; Dove, S.K.; van Iersal, M.W.; Thomas, P.A.; Ruter, J. Implementation of wireless sensor networks for irrigation control in three container nurseries. HortTechnology 2013, 23, 747-753. [CrossRef]

43. Warsaw, A.L.; Fernandez, R.T.; Cregg, B.M.; Andresen, J.A. Water conservation, growth, and water use efficiency of container-grown woody ornamentals irrigated based on daily water use. Hortic. Sci. 2009, 44, 1308-1318. [CrossRef]

44. Daniels, A.B.; Barnard, D.M.; Chapman, P.L.; Bauerle, W.L. Optimizing substrate moisture measurements in containerized nurseries. Hortic. Sci. 2012, 47, 98-104. [CrossRef]

(C) 2020 by the authors. Licensee MDPI, Basel, Switzerland. This article is an open access article distributed under the terms and conditions of the Creative Commons Attribution (CC BY) license (http://creativecommons.org/licenses/by/4.0/). 